\title{
Lilac Cultivar Name Registration 2004
}

\author{
Freek Vrugtman
} International Registrar, International Cultivar Registration Authority Genus Syringa L., Royal Botanical Gardens,
Box 399, Hamilton, Ontario L8N 3H8, Canada

All correspondence concerned with additional information or plants or propagules of newly registered lilac cultivars should be directed to the registrants listed below, not to the registrar.

Commencing with Lilac Registrations 1995 standard portfolios are being established in accordance with Division V: Nomenclatural Standards, of the International Code of Nomenclature for Cultivated Plants, 7 th ed. (ICNCP-2004).

Previous registration lists of Syringa cultivar names appeared in AABGA Bulletin [13(4):105-110; 14(3):95; 15(3):71-72; 16(4):131132; 17(3):67-69; 18(3):87]; HortScience [23(3):458;24(3):435-436; 25(6):618; 26(5):476-477; 29(9):972; 31(3):327-328; 32(4):587588; 33(4):588-589; 34(4):600; 35(4):549; 36(5):836; 37(7):1145; 38(6):1301; 39(6):1524].

Syringa L. (Villosae Group) 'Marie Rogers' was registered 9 Apr. 2003, by Professor Emeritus Owen M. Rogers, Plant Biology Department, University of New Hampshire, Durham, NH 038242617, and the late Walter W. Oakes (1928-2005) of Dixfield, Maine. The original plant was selected and named by W.W. Oakes in the late 1990s. It was selected from a batch of 1992 seedlings received from O.M. Rogers; these seedlings were open pollinated progeny of S. ×josiflexa '86-1' (Rogers, 1994). The selection first flowered in 1995; plants were first propagated in 1997. Commercial introduction will be by Syringa Plus, P.O. Box 363, 44 Belvedere Road, West Boxford, MA 01885. The selection was named by W.W. Oakes in 1999 for Marie Rogers, wife to O.M. Rogers. The 'Marie Rogers' lilac was selected for its compact thyrses and the radially double florets, two unusual characteristics in $S$. ×josiflexa cultivars and in the series Villosae C.K. Schneider in general. It is a large shrub to $4.5 \mathrm{~m}$; nonsuckering when on its own roots. Leaves are rugose; flowering is 10 to $14 \mathrm{~d}$ after most $S$. vulgaris cultivars; it has true terminal buds; thyrses are compact, not unlike those of $S$. vulgaris cultivars; it has fully formed flower buds with color Violet Group 71-A, opening to Violet Group 81-C [Royal Horticultural Society (RHS), 1995]; and $40 \%$ to $60 \%$ of the florets are radial doubles. Recommended propagation is through softwood cuttings taken at the time of full bloom. The cultivar is known to be hardy to USDA Zone 4.

A standard portfolio has been opened at Royal Botanical Gardens Herbarium, Hamilton, Ontario, Canada, but is still incomplete.

Syringa L. 'Purple Haze' $(S$. protolaciniata $\times S$. oblata subsp.


Canada. dilatata) was registered 18 Dec. 2003 by its originator Plant Propagator John H. Alexander, III, The Arnold Arboretum of Harvard University, 125 Arborway, Jamaica Plain, MA 02130-3519. The ortet or original plant (AA 2-92-C) from which the clone was derived originated in 1992. It was selected by Alexander from a group of six seedlings in May 2002. The parents of the controlled cross are $S$. protolaciniata (female AA 577-81-A; probably 'Kabul'; received as cuttings from the Botanic Garden of the University of Copenhagen, Denmark; coll. S.1966-1 of Klaus Ferdinand, collected in Barbur Jabul, Afghanistan), and S. oblata subsp. dilatata (male AA 789-67-A; vegetative propagation from AA 10202, collected by E.H. Wilson in North Kankyo, 35 $\mathrm{km}$ west of Yeiko, Korea). This is believed to be the first successful cross of these two species. Plants of this cultivar will be introduced and distributed by The Arnold Arboretum. Syringa 'Purple Haze' is a vigorous shrub with a globose habit. Leaves are similar to those of $S$. $\times$ chinensis, but occasionally lobate or laciniate. Flowering time coincides with that of $S$. $\times$ hyacinthiflora cultivars. Thyrses are 10 to $14 \mathrm{~cm}$ long, 5 to $7 \mathrm{~cm}$ wide; florets are 18 to $19 \mathrm{~mm}$ in diameter; corolla lobes are slightly reflexed; moderately fragrant. Flower bud color is Purple Group 75-A, opening to 75-B, eventually fading to 75-C (RHS, 1966, 1986). It is fully winter-hardy in USDA Zone 5, but not yet tested elsewhere. A standard portfolio has been opened at Royal Botanical Gardens Herbarium, Hamilton, Ontario, Canada, but is still incomplete.

Syringa pekinensis Rupr. 'Morton'-Peking lilac update

Jianhua Li, John Herbert Alexander, III, and Donglin Zhang demonstrated convincingly that $S$. pekinensis should be given species status. (Li et al., 2002). Accordingly, the botanical name Syringa pekinensis should be applied to the recently registered cultivar name 'Morton', which has been published in HortScience [38(6):1301].

\section{Literature Cited}

Li, Jianhua, J.H. Alexander, III, and D. Zhang. 2002. Paraphyletic Syringa (Oleaceae): Evidence from sequences of nuclear ribosomal DNA ITS and ETS regions. Systematic Botany. Quart. J. Amer. Soc. Plant Taxon. 27(3):592-597.

Rogers, O.M. 1994. Parentage of 86-1. Lilacs Quart. J. 23(4):107.

Royal Horticultural Society. 1966. Royal Horticultural Society colour chart. Royal Hort. Soc., U.K.

Royal Horticultural Society. 1986. Royal Horticultural Society colour chart. Royal Hort. Soc., U.K.

Royal Horticultural Society. 1995. Royal Horticultural Society colour chart. Royal Hort. Soc., U.K. 